CONFRONTING THE BOMB 
Stanford Nuclear Age Series

General Editor, Martin Sherwin

A DVISORY B OAR D

Barton J. Bernstein and David Holloway 


\section{CONFRONTING THE BOMB}

A Short History

of the

World Nuclear

Disarmament

Movement

LAWRENCE S. WITTNER

STANFORD UNIVERSITY PRESS

Stanford, California 2009 
Stanford University Press

Stanford, California

(C) 2009 by the Board of Trustees of the Leland Stanford Junior University. All rights reserved.

No part of this book may be reproduced or transmitted in any form or by any means, electronic or mechanical, including photocopying and recording, or in any information storage or retrieval system without the prior written permission of Stanford University Press.

Library of Congress Cataloging-in-Publication Data

Wittner, Lawrence S.

Confronting the bomb : a short history of the world nuclear disarmament movement / Lawrence S. Wittner.

p. cm. - (Stanford nuclear age series)

Includes index.

ISBN 978-0-8047-5631-o (cloth : alk. paper) -

ISBN 978-0-8047-5632-7 (pbk. : alk. paper)

1. Antinuclear movement-History. 2. Nuclear disarmament-

History. I. Title. II. Series: Stanford nuclear age series.

JZ5574.W58 2009

$327.1^{\prime} 74706-\mathrm{dc} 22$

2008055822

Printed in the United States of America on acid-free, archival-quality paper Typeset at Stanford University Press in 10/14 Minion 
To Merle Curti, who launched me on this journey long ago 
